\title{
Research on China's Shadow Banking Regulatory Issues
}

\author{
Rongxiang LUAN ${ }^{1, *}$ \\ ${ }^{1}$ Zhucheng Experimental school, Qingdao 266000, China \\ * Rongxiang LUAN. Email: wangqixin3@126.com
}

\begin{abstract}
After the 2008 financial crisis, most financial practitioners reflected on the causes of the financial crisis and believed that shadow banking was the root cause of the crisis. Although China's shadow banking started late, it has developed rapidly and has become a major hidden danger in China's economic operation. In 2016, after the regulatory authorities put forward the requirement of "deleveraging and preventing risks", the supervision of shadow banking has been continuously put on the agenda of important meetings, and the supervision of shadow banking has no time to delay. To this end, this article will clarify the concept and development of China's shadow banking, and analyze the typical and localized characteristics of China's shadow banking, so as to show the specific manifestations of risks. Finally, it will discuss the existing problems in China's current shadow banking supervision, and put forward suggestions in terms of supervisory concepts, supervisory systems, and financial reforms.
\end{abstract}

Keywords: shadow banking, risk performance, supervisory recommendations

\section{INTRODUCTION}

Shadow banking is a concept from Western countries. After the US subprime mortgage crisis in 2008, shadow banking began to attract the attention of the Chinese financial community. Shadow banking is a product of financial innovation, which can stimulate market vitality, improve the efficiency of capital allocation, and have a positive effect on promoting China's economic development. Therefore, from the beginning, the Chinese regulatory authorities took a wait-and-see attitude towards the development of shadow banking. However, as the scale of shadow banking continued to expand, the huge risks hidden in it began to gradually emerge. In 2013, the "Notice of the General Office of the State Council on Strengthening Shadow Banking Supervision Issues" promulgated by the State Council became a milestone in China's shadow banking supervision. Since then, shadow banking has gradually become the focus of supervision by China's financial regulatory authorities. In 2017, the Fifth National Financial Work Conference put the prevention and resolution of systemic risks as the primary battle of the three tough battles. Shadow banking has received special attention because of its prone to cause systemic risks. Therefore, how to strengthen the supervision of shadow banking while promoting the development of finance has become a major issue for all financial management institutions.

\section{LITERATURE REVIEW}

Facing the impact of shadow banking on financial stability, Chinese scholars have carried out a wealth of research on shadow banking, including:

Yi Xianrong was the first to express his views on shadow banking. He believes that the outbreak of the US financial crisis is essentially the collapse of the shadow banking system, and defines shadow banking as a financing method that is different from traditional commercial banks and transforms traditional credit relationships into another credit relationship through asset securitization [1]. He Dexu and Zheng Liansheng analyzed in detail the causes of shadow banking and the risks involved by discussing the causes of the outbreak of the US financial crisis. Ba Shusong believed that the supervision of shadow banking needs to strengthen information disclosure and information disclosure [2]. The opacity of information and the imperfect disclosure system are an important reason for the current shadow banking supervision effect [3]. Huang Tao agreed with Ba Shusong's point of view and proposed that "functional supervision" should be used instead of "institutional supervision" [4]. Yuan Dasong emphasized the importance of international cooperation, proposing that 
on the one hand, China should try its best to speed up the establishment of a legal supervision system, and on the other hand, it should strengthen cooperation with other countries. Sui Ping put forward the viewpoint of rating shadow banking on the supervision measures of shadow banking, and discussed the direction and measures of future supervision under the background of financial innovation [5]. Pan Jing and Chai Zhenguo pointed out the deficiencies of government supervision in shadow banking supervision, and proposed that market mechanisms should be introduced. Only when the two cooperate can effective supervision be achieved. Wang Zhaoxing reviewed the development of shadow banking and rethought the scope and functions of shadow banking [6]. Shen Wei analyzed every aspect of the risks of shadow banking, and provided a legal basis for the formulation of banking supervision policies. Guo Pei analyzed the similarities and differences between shadow banking in China and the shadow banking model in the United States [7], and pointed out that the root of shadow banking in China is not in the dual regulatory structure, but in financial repression and regulatory thinking, and proposed corresponding regulatory measures [8].

From the above literature, Chinese scholars have conducted research on China's shadow banking from the characteristics [9], risks, and supervision of shadow banking. However, China's shadow banking is constantly developing, its risks are constantly changing, and regulatory measures should keep pace with the times [10]. Therefore, the research on China's shadow banking supervision still needs to continue [11].

\section{OVERVIEW OF CHINA'S SHADOW BANKING BUSINESS DEVELOPMENT}

\subsection{The Concept of Shadow Banking in China}

The difference between the two is that they both have non-bank credit intermediary functions, and are not or less regulated by the banking regulatory system. The difference is that the shadow banking business in European and American countries is characterized by a high degree of securitization and derivation. Financial institutions participating in shadow banking business are often non-bank financial institutions, and they form a business network through the cooperation of various institutions and various tools. The financial market replaces specific institutions to play the role of credit intermediary. China's shadow banking mainly exists in the banking system. Banks are often directly involved in the chain. The main business is bank wealth management products and inter-bank business, which is actually an act of lending in disguise. Because this behavior has a partial substitution effect on the credit function of banks, some scholars believe that China's shadow banking is actually the shadow of banks. The concept of shadow banking in China has always been in a relatively vague state, and a unified standard has not been formed for a long time [12] Various scholars have given different definitions based on different research perspectives. The issuance of the "Notice of the General Office of the State Council on Strengthening the Supervision of Shadow Banking" (Circular 107) is a milestone in the supervision of shadow banking in China. It divides China's shadow banking into three types through generalization and enumeration, but It has still not been able to include all shadow banks in its scope [13]. At the same time, it is free from the banking supervision system and is not supervised or subject to less supervision, which poses systemic risks. Characteristic financial institution or business [14].

\subsection{The Development History of China's Shadow Banking}

During this stage, banks under strict supervision cooperated with trust institutions under less supervision to realize lending, and China's shadow banking took shape [15]; the second stage was the multi-channel stage from bank-trust cooperation to bank-securities cooperation occurred from 2012 to 2013 . At this stage, trust institutions received the attention of regulators due to their previous rapid expansion, and the new asset management regulations promulgated in 2012 expanded the scope of securities investment has led to a rapid increase in the scale of cooperation between banks and securities institutions. The third stage is the bank-base cooperation stage, which has taken place from 2014 to the present. During this stage, bank-trust and banksecurities cooperation are restricted, and fund subsidiaries have become the best partners for bank cooperation.

As China's understanding of shadow banking continues to deepen, the scale of China's shadow banking has experienced a rapid rise and then a steady decline. According to Moody's estimates, China's shadow banking development was slow before 2010, and reached its peak level in 2016, accounting for $87 \%$ of GDP. By the end of 2018, the scale of broad shadow banking was 61.3 trillion-yuan, accounting for $68 \%$ of GDP, the lowest level since the end of 2016. But the scale is still large, and risks still exist. At present, China's shadow banking can be divided into two categories based on the banking system. Among them, the shadow banking in the banking system is composed of commercial banks, insurance companies, trust companies and other financial institutions and their businesses. Since the wealth management products of banks are among the few products that can raise funds from the public and are at a higher credit level, they are raising funds. It has advantages in funding. 


\subsection{Basic Characteristics of China's Shadow Banking}

\section{(1) Free from supervision}

Leaving outside of supervision is a core feature of shadow banking. Because of the similarities between shadow banking and commercial banking, the risks of shadow banking are also comparable. On the one hand, because shadow banking bypasses the supervision of financial institutions through channel business, it is not restricted by regulatory requirements such as capital adequacy ratio and liquidity ratio. The profit-seeking motive makes it impossible for shadow banks to voluntarily adopt corresponding risk protection measures. This has greatly reduced the ability of shadow banks to absorb and bear risks. On the other hand, shadow banking is free from the supervision of the supervisory agency, which means it is free from the protection of the supervisory agency. Chinese regulators have set up three lines of defence to prevent the bankruptcy of commercial banks and other financial institutions. First, pre-qualification access; second, deposit insurance system; third, lender of last resort system. Shadow banking is not restricted by prior qualifications, and there may be problems with business models and risk management methods. The deposit insurance system cannot cover shadow banking.

\section{(2) Term mismatch}

Maturity mismatch is one of the basic characteristics of shadow banking. Maturity mismatch refers to the mismatch between the maturity of assets and the maturity of liabilities. The simplest term is to borrow short and long loans. Traditional commercial banks also mainly make profits in this way. But the problem is that commercial banks are subject to certain restrictions on the ratio of deposits and loans, maturity, and other aspects, and there are corresponding risk supporting measures. The unsupervised characteristics of shadow banks exacerbate the tendency of this maturity mismatch to obtain profits. Specifically, on the liability side, shadow banks mainly rely on wealth management products and interbank deposit certificates that have emerged in recent years for financing.

\section{(3) Liquidity conversion}

Liquidity is an important factor in determining the price of financial products. The higher the liquidity, the lower the product price, the lower the cost paid by the bank and the greater the profit. Shadow banking realizes liquidity conversion through maturity mismatch. It is mainly through product layered design, institutional rating and other means to convert products with poor liquidity but with future cash flow into products with high liquidity, and sell them to investors by classification. Liquidity conversion often adopts the mode of operation of the fund pool, that is, using the cash flow generated by the project and the funds of the later investors to purchase the product to repay the maturity income of the earlier investors. This capital pool model determines that the profit and loss of each investment is difficult to measure, and the losses incurred in the previous period can only be deposited in the capital pool.

\section{(4) Credit transfer}

The transfer of high-risk credit assets is an important motivation for shadow banking. Due to regulatory restrictions such as the loan-to-deposit ratio and capital adequacy ratio, one of the ways for Chinese commercial banks to expand their profits is to transfer high-risk assets off-balance sheet, so that there are fewer risk-weighted assets. With a certain rate, less capital can be occupied, so that capital can be used for other investments.

(5) Led by commercial banks

Unlike typical shadow banking in European and American countries, China's shadow banking is not a "parallel banking system" but a "shadow of banks." This is because China's shadow banking is dominated by commercial banks, circumventing supervision through shadow banking business, so as to achieve the purpose of broadening operating channels, reducing costs, and increasing profits. Specifically, banks' off-balance sheet businesses, especially wealth management products, have a natural advantage in absorbing funds, so they are mostly used as the source of shadow banking funds.

\section{(6) Mainly serve SMEs}

China's financial market is not well developed, and direct financing accounts for a relatively small proportion. Commercial banks, as the main indirect financing platform, have high thresholds due to limited funds and risk management requirements. Chinese SMEs have the characteristics of small scale and unstable operation, and it is difficult for them to meet the loan qualification requirements of commercial banks and other formal lending institutions, which makes it difficult for them to obtain sufficient development funds. The emergence of shadow banking has met the financing needs of some enterprises to a certain extent.

\section{ANALYSIS OF CHINA'S SHADOW BANKING SUPERVISION}

In response to the supervision of shadow banking, relevant departments in China have introduced a series of policies and measures. From 2016, the "deleveraging and risk control" has become the top priority of financial supervision. In 2018, the "Regulations on Regulating Asset Management Business of Financial Institutions" With the promulgation of the "Guiding Opinions", China has initially established a basic framework to prevent shadow banking risks, but there are still some problems. 


\subsection{Problems with Regulatory Concepts}

China's shadow banking supervision concept has the problem of excessive supervision of shadow banking and insufficient guidance. In 2013, the State Council issued Circular 107, proposing the regulatory concept of "correctly grasping the development and supervision of shadow banking". But in actual operation, this concept has not been effectively implemented. China's shadow banking often goes through a stage where it cannot be effectively guided and cleared in the early stage, but is directly suspended or punished after the risk has accumulated to a certain extent. Although this approach can control risks in a short period of time, the problems of shadow banking have not been actually solved, and new shadow banks will soon appear, causing the game between shadow banking and supervision to become more intense, leading to greater difficulty in supervision. And cause a waste of regulatory resources. At the same time, the practice of not directing the forced stop in the early stage will easily cause the accumulated risks of shadow banking to burst out at once, affect multiple economic entities, and easily cause systemic risks. In addition, this practice hinders China's financial innovation to a certain extent, and is not conducive to the activeness of market funds and the prosperity of the financial market.

\subsection{The Regulatory System does not Adapt to Actual Development}

(1) Separate industry supervision is contrary to reality

With the establishment of the Financial Stability and Development Committee of the State Council in 2017 and the merger of the China Banking Regulatory Commission and the China Insurance Regulatory Commission in 2018, China has formed a regulatory system of "one committee, one committee and two committees", but it is still difficult to adapt to the development of shadow banking. First of all, the relationship and responsibilities between the Financial Stability Board, the China Banking Insurance Commission and the China Securities Regulatory Commission are not clear. The macro-prudential supervision framework is in its infancy, and China is still focusing on micro-prudential supervision. Secondly, China still belongs to a separate supervision model, and the mixed operation of shadow banking breaks through the existing supervision pattern. On the one hand, traditional institutional supervision methods will lead to a regulatory vacuum. On the other hand, they will often fall into cumbersome detailed reviews due to the mixed operation of shadow banking services. The new risks of cross-business operations are restricted by their professionalism. In the process, it is easy to lose the ability of discrimination, which reduces the efficiency and authority of supervision. Moreover, under the separate supervision model, there is a lack of effective information sharing mechanisms between various institutions. For risk information that is dynamic in nature and needs to be updated in real time, it is impossible to achieve timely information exchange between various regulatory agencies, which is also not conducive to the shadow Control of bank systemic risks.

(2) The legal system is not perfect

The law is the most authoritative and important basis for the supervision of shadow banking, but China's laws on shadow banking supervision have the problem of unclear legislation or low level of legislation. First of all, China does not have a special supervision law for shadow banking. It is only slightly involved in different laws according to different forms of shadow banking. There is a lack of legal guidance and restraint. The supervision of shadow banking lacks the most important "weapons". Secondly, with the continuous innovation of finance, the definition of certain financial products in China's existing laws has been too narrow, which has caused the regulatory agencies to be at a loss when conducting supervision. For example, the definition of securities in China's "Securities Law" is based on the organization's membership. The thinking is limited, and the financial product contracts issued by banks are excluded from the scope of securities. In addition, there are some conflicts between some of the current regulatory documents and higher-level laws. For example, the "New Asset Management Regulations" and the "Funds Law" both stipulate the procedures to be followed to change product investment. The "New Asset Management Regulations" require investors' written consent as a necessary procedure, but it does not stipulate the proportion of consent required. Projects with high-risk to low-risk transitions are exceptions to this procedure; Someone voted at the meeting, requiring more than two-thirds of the voting rights to pass, and there is no exception clause. According to the rules applicable to the law, when there are conflicts in regulations, the "Funds Law", as a law, has a higher legal rank than the "New Asset Management Regulations" and other departmental normative documents, and should be applied first. However, the "New Asset Management Regulations" are a summary of the experience of financial supervision in recent years and are more in line with the development of the times. According to the provisions of the Funds Law, it may be difficult to achieve the expected regulatory effects. Therefore, in order to ensure the effectiveness and authority of supervision, the legal system needs to be further improved to provide the strongest guarantee for supervision.

\subsection{Ignore the Fundamental Cause of Shadow Banking-Financial Repression}

The background of China's shadow banking is that the regulatory rules have formed financial repression for 
a long time, which has led to the mismatch between the financial market's capital demand and the capital supply. Therefore, the regulatory situation has become more stringent and shadow banking businesses have emerged one after another. On the one hand, on the capital supply side, as the disposable income of Chinese residents continues to increase, their investment demand has also increased. However, due to the underdeveloped financial market in China, the investment channels available to investors are very limited. In the field of short-term investment, investment Almost can only choose bank deposits. At the same time, because Chinese banks are subject to interest rate controls for a long time, deposit rates are often lower than market rates, which is not attractive to investors. On the other hand, on the capital demand side, China's financial resource allocation is unfair, and most bank loans flow to state-owned enterprises and listed companies. The financing needs of other companies are often difficult to meet. In addition, for financial institutions that connect the capital demand side and the capital supply side, measures such as interest rate control have made banks insufficient to absorb deposits, and policies such as high deposit reserve requirements and strict loan-to-deposit ratios make the profitability of banks limited; non-bank financial the situation facing institutions is even more severe. From this perspective, the credit intermediary activities carried out by shadow banking to break through regulatory restrictions are actually a self-correction of financial repression policies.

\section{REGULATORY RECOMMENDATIONS FOR CHINA'S SHADOW BANKING}

The emergence of shadow banking stems from the pursuit of high-yield regulatory arbitrage. As long as there are regulatory loopholes, new forms of business evading regulation will emerge. Therefore, it is better to prevent the risks of shadow banking than to prevent them. On the one hand, it is necessary to establish correct supervisory concepts and provide correct ideas and directions for shadow banking supervision; on the other hand, it is necessary to establish a macro-micro prudential supervision system to lay a solid institutional foundation for risk prevention; in addition, it is necessary to accelerate China's financial The reform process will improve the various systems of the financial system and guide the healthy development of shadow banking.

\subsection{Establish a Correct Supervision Concept}

To establish a correct regulatory concept, it is important to coordinate the relationship between financial innovation and financial stability. On the one hand, shadow banking plays an important role in China's financial development. Shadow banking provides financing channels for many SMEs in China. Its development is conducive to stimulating the vitality of
China's economy, continuously improving the financial market, and having a positive effect on financial development. On the other hand, shadow banking is a product of regulatory arbitrage. If shadow banking is allowed to grow wildly, it will obviously cause great hidden dangers and have a negative effect on China's financial stability. Therefore, we should grasp the relationship between financial innovation and financial stability. Regulators should not only give enough room for the development of shadow banking innovation, but also guide shadow banking to play its active role. In addition, it is necessary to conduct reasonable supervision, insist that financial stability is the foundation of financial innovation, and supervision should be based on the concept of financial stability value. The direction of shadow banking supervision should be changed from regulation and restriction to diversion and guidance, and compulsory management should be transformed into correct guidance. It is necessary to pay proper attention in the early stage, dredge risks in the mid-term, and guide the development of compliance in the later stage to escort financial innovation. It is not possible to take supervisory measures that wait until the concentration of risks is too large to stop directly. China's problems need to be solved continuously through economic development. Correct supervision concepts should be established, and more importantly, they should be implemented.

\subsection{Continue to Improve the Regulatory System}

(1) Build a realistic supervision system

Shadow banking has the characteristics of crossindustry operations and cross-infection of risks. With the accelerated development of shadow banking, the current micro-prudential regulatory framework has exposed many problems. The establishment of the Financial Stability and Development Committee of the State Council has brought an opportunity to build a macroprudential regulatory framework to strengthen the coordination of supervision of various departments. First, it is necessary to clearly distinguish the relationship and responsibilities of the Financial Stability Development Committee and the "One Bank and Two Committees" on shadow banking supervision issues. As the coordinating agency for macro-prudential supervision, the Financial Stability and Development Commission can formulate macro policies for China's shadow banking supervision on the one hand, and on the other hand can preside over the coordination of regulatory conflicts. The People's Bank of China can act as the maker of specific regulatory measures for shadow banking and provide advice on the formulation of macro policies of the Financial Development and Stability Committee. The "Two Sessions" are the direct supervisory agencies of China's shadow banking and accept the supervision of the Financial Stability and 
Development Commission of the State Council. Supervisory information must be reported to the Financial Stability and Development Commission and the Central Bank in both directions. Second, government financial management departments must be included in the macro-prudential regulatory agency system to solve a series of problems such as unclear division of regulatory responsibilities and inconsistent regulatory standards. Finally, it is necessary to build a shadow banking information sharing platform to reduce regulatory vacuum and regulatory loopholes.

(2) Improve relevant laws and regulations

China's existing laws on related shadow banking are not yet complete, and lack specific and professional requirements. Therefore, legislation on shadow banking supervision should be accelerated so that the supervision of shadow banking can be followed by law. First, we must revise existing legislation. On the one hand, it is necessary to revise the existing laws that are no longer suitable for financial development, such as the securities and trust concepts in the Securities Law and the Measures for the Administration of Trust Companies. Specifically, the definition of securities should adopt business functionalism Instead of institutionalism, financial product contracts issued by non-securities companies such as banks, insurance companies, and fund companies are included under the supervision of the Securities Law. The definition of trust is the same. On the other hand, the "Guiding Opinions on Regulating the Asset Management Business of Financial Institutions" has made relatively comprehensive provisions on the supervision of shadow banking, which can be used as a reference to improve shadow banking with banking, insurance, securities and trust as the main business areas Supervise legislation and raise the legal hierarchy to make shadow banking supervision more targeted and authoritative. Secondly, it is necessary to fill the legal gap. Private finance and Internet finance are the areas where shadow banking is relatively active and the most under-regulated. At present, the only laws and regulations are issued by local governments. There are regional differences. Therefore, it is necessary to speed up the identification of supervisory bodies and unify supervisory standards.

\subsection{Accelerate the Pace of China's Financial Reform}

(1) Speed up the process of interest rate marketization

China's shadow banking is a product of strict supervision, and one of the important aspects is interest rate control. Commercial banks' deposits and loans are subject to interest rate control, and their deposit rates are lower than the market level, making it difficult to attract depositors. They are also subject to the control of credit lines and loan directions, and loan interest rates are generally higher. However, the demand for funds in the financial market is strong. In the face of this situation, in order to absorb capital and create profits, commercial banks and other financial institutions will find ways to circumvent regulations through financial innovation while providing products with higher interest rates. Shadow banking emerged spontaneously in this situation. Therefore, the interest rate control of commercial banks should be gradually eliminated, interest rate liberalization should be realized, and banks should be given room to operate freely and inspire them to create new compliant and attractive deposit products and other financial products. At the same time, it is necessary to innovate to use various regulatory indicators to ensure the stability of bank operations. Because commercial banks have advantages such as economies of scale, when interest rates are fully market-oriented, they will reduce the profitability of shadow banking credit intermediary businesses, and make them voluntarily abandon the same short-term loan long-term profit model as banks and switch to other business areas. China's interest rate marketization has been going on for many years. Although the level is still immature, certain experience has been accumulated. We should seize the opportunity of China's economic transition to highquality development and continue to accelerate the process of interest rate marketization.

(2) Improve China's monetary policy adjustment system

The credit creation function of shadow banking has a negative impact on the effectiveness of China's monetary policy regulation. Therefore, it is necessary to improve China's monetary policy adjustment system and include shadow banking in the scope of regulation. First, we must change the monetary statistics system implemented by China's central bank. First, we must revise the scope of money supply statistics, and include financial instruments with strong currency attributes and high market shares into the money supply statistics category. Second, we must improve the statistics of the total amount of social financing, so that the credit created by shadow banking can also be included, and manage the total gate of the money supply. Second, China mainly uses a quantitative monetary policy. However, with the acceleration of financial innovation, the speed of currency circulation is no longer stable, and the currency edge is gradually blurred.

(3) Guiding the healthy development of shadow banking

While shadow banking circumvents regulatory constraints and brings huge challenges to financial stability, it has also become the real economy, especially providing important financing channels for many small and medium-sized enterprises. Therefore, on the one hand, it is necessary to guide the shadow banking business in financial institutions to gradually enter a 
standardized development; on the other hand, to strengthen the cooperation between non-financial institutions and financial institutions, expand the development space of non-financial institutions, and reduce the living space of shadow banking. Regarding off-balance sheet business of banks, supervisory authorities should adopt business substance supervision and continuously improve accounting standards. At the same time, it is necessary to gradually achieve consolidation and complete credit conversion. Regarding trust businesses, it is necessary to further strengthen the monitoring of trust asset investment, improve the transparency of trust businesses, and promote the standardized provision of financial services. Regarding private finance, private lending and $\mathrm{P} 2 \mathrm{P}$ lending can be incorporated into the regulated financial system, a private fund monitoring system will be established, and a compliant trading platform will be established to standardize transaction entities and transaction procedures and keep abreast of the dynamics of private financial activities. The cooperation between nonfinancial institutions and financial institutions can be mainly reflected in two aspects. First, it can realize the circulation of customers, that is, to introduce customers who do not meet one's own side but may meet the requirements of the other party to the other party, reducing the cost of information search for both parties; second, it can be achieved Technology sharing. As the main practitioners of financial technology, informal financial institutions, especially those related to the Internet, have unique data collection and analysis technologies. Through technology sharing, it is beneficial to broaden the borrowing channels of both parties.

\section{CONCLUSION}

China's shadow banking is a product of financial innovation under the background of financial repression. On the one hand, China's shadow banking has the typical characteristics of shadow banking in European and American countries, which brings huge hidden dangers to financial stability; but it also has its own local characteristics, that is, it is dominated by commercial banking systems. Funds mainly flow to small and medium-sized enterprises and local financing platforms, etc., with non-disintermediation and certain functions of serving the real economy. Based on the analysis of China's current regulatory measures and existing problems, this article believes that the supervision of shadow banking must not only establish a correct concept, grasp the relationship between financial stability and financial development, but also continuously improve the financial regulatory system and strengthen shadow banking. Bank supervision should be coordinated to reduce supervisory arbitrage. It is also necessary to speed up the process of China's financial reform, accelerate China's interest rate market reform, improve monetary policy, create a good financial market environment, and guide the healthy development of shadow banking.

\section{REFERENCES}

[1] Zhao Zeyun. Analysis of the development and supervision of China's shadow banking $[\mathrm{J}]$. China Collective Economy, 2019(02):102-103.

[2] Guo Li. The risk traceability and regulatory innovation of Chinese shadow banking[J]. China Law, 2018(03):206-227.

[3] Zhou Shunxing. Shadow Banking and Small and Medium Commercial Banks' Risk-taking: Transmission Mechanism and Empirical Research[J]. Financial Supervision Research, 2018(08): 78-92.

[4] Zhou Xiwen. Research on the Risk and Supervision of Chinese Shadow Banking[J]. Modern Business, 2018(18): 124-125.

[5] Zheng Xin, Sun Junchao, Wang Qian. Research on the Legal Supervision of China's Shadow Banking[J]. Financial Economics, 2018(16): 74-76.

[6] Wang Zhe, Zhang Ming, Liu Shida. From "channel" to "industry"— The evolution process, potential risks and development direction of China's shadow banking system[J]. International Economic Review, 2017(04): 128-148 +8.

[7] Fan Tieguang, Jin Tao. Why has the supervision of shadow banking been so difficult? $[\mathrm{J}]$. The Banker, 2017(07): 72-74.

[8] Ba Shusong. The regulatory trend of shadow banking in China[J]. Tsinghua Financial Review, 2017(11): 31-32.

[9] Shen Wei. The Shadow of Banks: An Analysis Framework of Shadow Banking Centered on Banking Law [J]. Tsinghua Law Science, 2017, 11(06): 25-48.

[10] Zheng Xin, Sun Junchao, Wang Qian. Research on the Legal Supervision of China's Shadow Banking[J]. Financial Economics, 2017(16): 74-76.

[11] Wang Zhaoxing. Rethinking of Shadow Banking and Its Governance_-The Ninth Exploration of Banking Regulatory Reform $[\mathrm{J}]$. China Finance, 2017(07): 11-15.

[12] Liu Chao, Ma Yujie. The impact of the shadow banking system on China's financial development and financial stability: An analysis based on monthly data from 2002 to 2012 [J]. Economist, 2016(04): 72-80. 
[13] Yuan Dasong. The reform of the international financial legal system to strengthen the supervision of shadow banking[J]. Legal Studies, 2016(2): 194208.

[14] Huang Tao. The legal path of China's financial market from institutional supervision to functional supervision[J]. Legal Studies, 2016(7): 24.

[15] Ba Shusong. Strengthening the supervision of the shadow banking system China Finance[J]. 2016(4):167-168. 